\title{
Troubled Students Handling Through Scientific-Based Law Approach Strategy
}

\author{
Milwan \\ Teacher at SMP Negeri 9 Kendari, Southeast Sulawesi, Indonesia
}

\begin{abstract}
This study was motivated by the variety of student behavior enjoyed by teachers every day even in the classroom even while the learning process. Still the number of male students, in and out of the classroom, and ultimately manifested in the learning process is not effective even for a fight, the discovery of the students who take the stuff that is not right, suck Glue Fox, persecute so this behavior is classified into students problematic. The purpose of this study was to determine: (1) Model-Scientific based law approach in troubled students handling at SMPN 17 Kendari; (2) The application of the model-approach based on the positive changes in attitudes and behavior in everyday life. Research Best Practice results are (1) Handling of troubled students through a strategic approach based on scientific studies of all subjects can improve school attendance. Increased student attendance has reached a percentage of $96.87 \%$. Previously while still in grade VIII Semester 2 percentage attendance only reached 64\%. (2) Proved that before the application of handling troubled students through a strategic approach based on science and technology. If somebody does something to harm the order, recapitulation violations of discipline students, after the adoption of handling troubled students through a strategic approach to the law based on scientifically proven that there is a diligently arrive at school on time so That it can follow a morning assembly, all already dressed in uniforms that is set by the school, it is rare students who are late to class, so maintaining the cleanliness of the school environment so it does not appear again there Are students who throw garbage anywhere, assignments or homework given by teachers of subjects already done at home and working in groups.

Handling troubled students through a strategic approach based law Scientific is a real effort made by SMP Negeri 17 Kendari can create a learning environment that is creative, innovative and fun so that student learning outcomes can be improved.
\end{abstract}

Keywords: Troubled Students Handling, Scientific-Based Law Approach Strategy

\section{Introduction}

National Education aims to educate the life of the nation and develops a complete humanity of Indonesia, the man who cautious to God Almighty, and virtuous noble character, possessing knowledge and skills, physical and spiritual health, a stable and independent personality, and a sense Of community responsibility and nationality. Faith and piety are very important in one's existence as an essential controlling and weighing tool to distinguish right and wrong. Without human faith will fall into the depths of shame, harm himself and his environment. Our educational world today faces a very complex problem that needs to get our attention. One of the problems is the decline in social life and moral ethics in the practice of school life which resulted in a number of negative excesses that are deeply troubling for the community. These excesses include the increasingly widespread deviations from various religious and social norms of life which is the subject of life and the lack of discipline over time and ignore the existing rules of the school, lacking the beauty and hygiene Environment, drug use, fights between students.

\section{Literature Review}

The concept of the research is done by the principal in the form of school management that is a scientific-based approach to legal approach. The meaning of strategy is the method used in doing something. According to Apriani Fitri (2004: 63) that strategy is the way that someone does to get the result set. According to Harli Dawi (2008: 84) that the strategy is an effort made someone to achieve the goals that have been set first. So strategy is a technique, methods, ways and approach used in doing activities to achieve something desired, aspired. The developed program is oriented towards the capacity and school climate of SMPN 17 Kendari and is characterized by the leadership management pattern. This is done to improve the character education of the students in carrying out their duties or obligations in support of better and superior school learning activities compared to other schools or equivalent schools. According to Dorothy (2008: 97) that problem solving is a problem of adults and at the same time the problem of children. In this activity the model 
of school development approach in the form of a scientific-based law approach is decomposed in a simple that has been implemented, so That the program plan continuation is continuous. This activity uses a five-step system developed by Dorothy (2008: 99), the five-step system is:

One : What's the problem?

Two : What do we do?

Three : What did we try first?

Four : How do we know it works?

Five : What do we do next?

This is what scientific values are. Scientific values in question, not just fill the instrument, but ask for the process of the incident, collect information on the case, processing data on four agencies, knowing sanctions in the Criminal Code and communicate to Fellow students. Based on the above analysis, it was found that students who have spare time are more likely to have misbehavior or deviant behavior. Similarly, from families with low social functionality, it is likely that their children will perform delinquency at a more severe level..

\section{Methodology}

A. Stage of Preparation At this stage, the authors present the tools and materials that will be prepared, divide the students into groups, and determine the schedule of activities. Students are divided into 6 groups consisting of 6 people in one group. Each group handles one case guided by one teacher each. The following are the names of the groups and cases handled:

1. Group I is a group that handles the problem of theft case, consisting of 6 students, namely: Ananta Dara Dinanti, Muamar Fadil Shah, Eki Saputra, Rina Reski Amalia, Putri Andriani, Muh.Dandy, and the name of supervisor Bastin, S. Pd.

2. Group II is a group that handles Fighting case problem, consisting of 6 students, namely: Artillery, Darmin, Iksan Anugrah, Alfitra Zulhija, Irma Yunitha Putri, Erlangga Setiawan and Serly Putriani, S.Pd.

3. Group III is a group that handles cases of Unpleasant Acts, consisting of 6 students, namely: Septi Estianti, Sitti Nurhalisa, Theo, Rahmad Wahyudi, Rifkiyanto Maulud, Patri, and name of supervisor La Halisi, S.Pd.

4. Group IV is a group dealing with Sexual Harassment case, consisting of 6 students, namely: Rahmasari Safilda, Erlangga Madjid.L, Research Serine, Dilan, Adrian, Purnama Niecco .MY, and name of supervisor Hj. Ria Kustiyah, S.Pd.

5. Group V is the group dealing with the case of Persecution, consisting of 6 students, namely: Rasti Kurniati Arman, Yusril Nasim Mandara, Satrio Fri, Ayu Dwi Maharani, Ira Akib, Anjawan, and supervisor is Heriani, S.Pd. , M.Pd.

6. Group VI is a group that handles the Drug case problem, consisting of 6 students ie on behalf of: Aisya Zulhijah, Stevia, Muh.Reza Pablevy, Muh. Gratitude, Muh.Syahrian, Early Pastika Ramadan, and the name of supervisor is Asniah, S.Pd.

\section{Result And Discussion}

The implementation of Best Practice was conducted during 2 weeks visit and 4 months of observation. The observed thing is to record how the development of attitude change from learners which amounted to 36 people, before conducting an assessment and searching cases and convicts in the three agencies. Stage of this best practice first the author of conveyed the scenario or outline that will be done on three agencies. The processes of activities carried out are:

1. Police Office of Kendari Resort (Polres)

a) Students are divided into 6 groups with 6 members of heterogeneous learning groups Each group.

b) All students with 36 people and 6 accompanying teachers headed to the Kendari Police Resort office, at a distance of $\pm 9 \mathrm{~km}$ from the school, located on Jalan DI Panjaitan No.1 Kendari city, students bring questionnaires to study the process of handling the cases Reported in accord tasks of each group that has been established.

c) Each group observed the case in the police station to fill out the questionnaire, by: questioning the process of occurring, collecting information on the case, processing the data, knowing the legal sanction and communicating to other fellow students.

d) The whole group went to the cell of Sel, to watch the captured and then put into the bars of the prisoners. From the whole process of filling the above scientific-based instruments, given time for 90 minutes. 
e) After 90 minutes, the whole group gathered in the Police Hall to discuss and summarize their findings by presenting in front of each group in turn. This activity is guided by 6 teachers.

f) After each group concludes the results of the discussion, then from the police (KAPOLRES) provide directions on the problems in the Police, while delivering punishment for violators contained in the articles of the Criminal Code.

g) Back to SMPN 17 Kendari, for preparation to State Class IIA Kendari Prison.

2. The Office of Detention House Class IIA Kendari

a) All students with 36 persons and 6 companion teachers are Kendari Class IIA Detention Center, with distance of $\pm 5 \mathrm{~km}$ from school, located at Jalan Letjend R.Suprapto No.112 Punggolaka Village, Puuwatu Sub district, Kendari City.

b) For the purpose of this activity, all the students gathered in the House of Detention Center to listen to the guidance of the escort and the Head of Detention Unit of IIA Kendari Class, to listen to the scenario of the activity to be performed.

c) Each group filled out the questionnaires by asking the chief officer who was competent in Detention Center Class IIA Kendari with 60 minutes.

d) The whole group watched, watched and documented the inmates' occupants.

e) All the students gathered in the room of Class IIA Kendari Detention Center, to receive a religious lecture by Ust. Ja'Hadah, S.Ag. M.PdI.

\section{Kendari District Court Office}

a) All students with 36 persons and 6 companion teachers go to the second office in Kendari District Court, with distance of $\pm 8 \mathrm{~km}$ from school, located at Jalan Mayjend Soetoyo no. 37 West Kendari Village Kec.Kendari Barat Kendari City.

b) All the students attended to the judicial process at the Kendari District Court office. The attendance of the 36 students attended to all decisions for violators: Theft, Fighting, Unpleasant Acts, Sexual Harassment, Ill-Treatment and Drugs.

c) After the result of the decision was read then the student witnessed the suspect who had become a convict was herded into a prisoner car for subsequent to take to Penitentiary.

d) Students visit in the cell cell of detention of Kendari District Court to witness the cell in prison.

4. Regional Office of the Ministry of Law and Human Rights of Southeast Sulawesi

All students with 36 persons and 6 accompanying teachers receive material from the Ministry of Law and Human Rights Offices to socialize awareness and legal obedience among students. The methods undertaken in this activity are lectures, discussions and Q \& A. This activity is done at SMPN 17 Kendari.

5. The Terrorism Prevention Communication Forum

\section{All students with a total of 36 people and 6 accompanying teachers received a material presentation on: \\ a) Socialization of radical ideology in Indonesia. \\ b) Socialization and public protection against acts of terrorism}

The methods undertaken in this activity are lectures, discussions and Q \& A. This activity was held at SMPN 17 Kendari.

\section{Time and place}

Implementation of this activity is done in the second semester of academic year 2015/2016, can be seen in table 1. Follows: 
Table 1. Implementation of this activity is done in the second semester of academic year 2015/2016

\begin{tabular}{|c|c|c|c|}
\hline $\begin{array}{l}\mathbf{N} \\
0 .\end{array}$ & Description of activities & $\begin{array}{c}\text { Schedule of } \\
\text { Implementation }\end{array}$ & Place of execution \\
\hline 1. & Coordination with 6 agencies & Date 9 to 11 May 2016 & $\begin{array}{l}\text { Kendari Police Station Office; } \\
\text { State Detention House Class IIA Kendari; } \\
\text { Kendari District Court Office; } \\
\text { Kendari Class IIA Penitentiary; } \\
\text { Regional Office of the Ministry of Justice and Human Rights } \\
\text { Prop.Sultra; } \\
\text { Terrorism Prevention CommunicationForum Southeast Sulawesi } \\
\text { province }\end{array}$ \\
\hline 2. & MoU signing & Date 12 till 14 May 2016 & $\begin{array}{l}\text { Kendari Police Station Office; } \\
\text { State Detention House Class IIA Kendari; } \\
\text { Kendari District Court Office; } \\
\text { Kendari Class IIA Penitentiary; } \\
\text { Regional Office of the Ministry of Justice and Human Rights } \\
\text { Prop.Sultra; } \\
\text { Forum communication Prevention Terrorist Prop. Southeast } \\
\text { Sulawesi. }\end{array}$ \\
\hline 3. & Study Cases reported at Polres Kendari & May $17^{2} 2016$ & Visit at Kendari Police Station (Polres) \\
\hline 4. & $\begin{array}{l}\text { Study to see Nara Penitentiary in State Penitentiary Clas } 5 \\
\text { IIA Kendari }\end{array}$ & Date 19 May 2016 & State Detention House Class IIA Kendari \\
\hline 5. & Study to attend court decision in Kendari District Court & Date 20 to 30 May 2016 & Kendari District Court \\
\hline 6. & Visit in Penitentiary & June $2^{25} 2016$ & Penitentiary Institute (LAPAS) Kendari. \\
\hline 7. & $\begin{array}{l}\text { - Socialization to Participants Educate about awareness } \\
\text { and obedience Law among students. } \\
\text { - Socialization to Participants Educate about Protection } \\
\text { Child. } \\
\text { - Discussion, Question and answer about Counseling } \\
\text { Law to Participants Educate }\end{array}$ & Date. 4 to 6 June 2016 & In Classroom SMPN 17 Kendari \\
\hline & $\begin{array}{l}\text { - Give socialization to Participants Educate about } \\
\text { danger Terrorism } \\
\text { - Give socialization toParticipants Educate aboutUnderstan } \\
\text { dings radical inIndonesia. } \\
\text { - Discussion and FAQ }\end{array}$ & From 13 to 14 June 2016 & In Clas sroom SMPN17 Kendari \\
\hline 9. & $\begin{array}{l}\text { Pesantren Kilat on Holy Ramadhan: Raligious lectures, } \\
\text { group discussions, Tadarrus Alqur'an, Sunnah Prayer and } \\
\text { obligatory in congregation. }\end{array}$ & Date. 15 to 22 June 2016 & Clas sroom, Room Hall, and Mosque SMPN 17 Kendari \\
\hline 10 & $\begin{array}{l}\text { - Attitude and Behavior Concern for the rules or rules in the } \\
\text { school that include: } \\
\text { - Presence in school } \\
\text { - Activeness in PBM } \\
\text { - Accuracy time in school } \\
\text { - Concern to clothes uniform school } \\
\text { - Concern to cleanliness's environment school } \\
\text { - Concern to PR task for all eye Lesson } \\
\text { - Manners and Rules of Conduct Life Social School }\end{array}$ & $\begin{array}{c}4 \text { months } \\
\text { (Date } 11 \text { July to } 30 \text { October } \\
\text { 2016) }\end{array}$ & $\begin{array}{l}\text { At SMPN } 17 \text { Kendari and in the Family Environment of each } \\
\text { Student. }\end{array}$ \\
\hline 11 & \multicolumn{3}{|l|}{ Completion of Activity Results } \\
\hline
\end{tabular}

\section{The results obtained}

The results obtained after conducting a study in three visits targets in a scientific-based legal approach as well as providing socialization from the Regional Office of Law and Human Rights and the Socialization of the Terrorism Prevention Communication Forum are:

\section{From the Attitudinal Behavior aspect in school}

Based on presentations of calculation results, proven with attendance data or attendance for 4 months, stating with problem students handling through a scientific-based legal approach in the learning of all subjects can increase the attendance rate of students. The attendance of students has increased has reached the percentage of $96.87 \%$. Previously in the second grade of VIII Semester 2 the percentage of attendance only reached $64 \%$. The enforcement of discipline at SMPN 17 Kendari is not only related to the issue of attendance or not, too late or not. It refers more to the formation of an environment in which it is a common rule that is respected, and whoever violates must dare to account for his actions. Any violation of the public interest in the school should be rewarded with an educational punishment so that the student is able to know the value of the discipline, but for the wider purpose of stability and peace of life together. For 4 months, the overall discipline behavior of grade IX.1 SMPN 17 Kendari students in following the learning process is increasing. The provisions of Office of Law and Human Rights and Socialization of the Prevention of Prevention Forum Terrorists. This data can be seen in the following table: 
For 6 Months (January to December 2015)

\begin{tabular}{|c|c|c|c|c|c|c|c|c|}
\hline \multirow[t]{2}{*}{ No } & \multirow[t]{2}{*}{ N ama } & \multicolumn{6}{|c|}{ Amount of Absence (alpha) } & \multirow[t]{2}{*}{ Tota } \\
\hline & & Jan. & Feb. & March & April & May & June. & \\
\hline 1 & Artileri & 5 & 2 & 4 & 3 & 2 & 5 & 23 \\
\hline 2 & Al-Fitra Zulhija & 2 & 3 & 1 & 3 & 2 & 6 & 17 \\
\hline 3 & Ananta Dara Dinanti & 3 & 5 & 2 & 2 & 4 & 3 & 19 \\
\hline 4 & Ayu Dwi Maharani & 2 & 4 & 1 & 2 & 2 & 5 & 16 \\
\hline 5 & Darmin & 2 & 3 & 4 & 3 & - & 4 & 16 \\
\hline 6 & Erlangga Madjid Lourens & 1 & 2 & 3 & - & 4 & 2 & 12 \\
\hline 7 & Feri Satrio & 2 & 3 & 6 & 2 & - & 3 & 16 \\
\hline 8 & Iksan Anugrah & 2 & 5 & 2 & 2 & 4 & 2 & 17 \\
\hline 9 & Ira Akib & 1 & 3 & 2 & 3 & 2 & 4 & 15 \\
\hline 10 & Muamar Fadil Syah & 3 & 2 & 4 & 3 & 2 & 2 & 16 \\
\hline 11 & Muh.Reza Pablevy & 1 & 4 & 4 & 3 & - & 2 & 14 \\
\hline 12 & Muh.Dandi Qimzal & 4 & - & 3 & 3 & 1 & 2 & 13 \\
\hline 13 & Muh.Sukur & 4 & 2 & 1 & 3 & - & 4 & 14 \\
\hline 14 & Muh. Syahrian & 1 & 3 & 4 & 2 & 3 & 1 & 14 \\
\hline 15 & Purnama Niecco Mossa.Y & 2 & 4 & 3 & 1 & 4 & 2 & 16 \\
\hline 16 & Putri Andriani & 1 & 2 & 2 & 3 & 3 & 2 & 13 \\
\hline 17 & Rahmad Wahyudin & - & 1 & 2 & 3 & 5 & 4 & 15 \\
\hline 18 & Rasti Kurmiati Arman & 2 & 1 & 4 & 3 & 2 & 4 & 16 \\
\hline 19 & Rifkiyanto Maulud Rahim & 1 & 3 & 1 & 4 & 3 & 2 & 14 \\
\hline 20 & Risal Serentu & 1 & 2 & 5 & 3 & 2 & 3 & 16 \\
\hline 21 & Septi Estianti & 4 & 2 & 4 & 2 & 1 & 6 & 19 \\
\hline 22 & Yusril Nazim Mandara & 3 & 2 & 1 & 3 & 6 & 5 & 20 \\
\hline 23 & Irma Yunitha Putri & 2 & 2 & 4 & 3 & 3 & 3 & 17 \\
\hline 24. & Rina Reski Amalia & 1 & 2 & 2 & 3 & 1 & 2 & 11 \\
\hline 25 & Eki Saputra & 3 & 6 & 1 & 4 & 1 & 3 & 18 \\
\hline 26 & Anjawan & 2 & 3 & 5 & 3 & 2 & 3 & 18 \\
\hline 27 & Awal Pastika Ramadhan & 3 & 4 & 2 & 2 & 5 & 5 & 21 \\
\hline 28 & Stevia & 3 & 2 & 3 & 3 & 3 & 4 & 18 \\
\hline 29 & Aisya Zulhijah & 2 & 6 & 3 & 1 & 5 & 3 & 20 \\
\hline 30 & Rahmasari Safilda & 6 & 4 & 3 & 2 & 2 & 5 & 22 \\
\hline 31 & Dilan & 3 & 5 & 4 & 2 & 3 & 2 & 19 \\
\hline 32 & Adrian & 2 & 3 & 2 & 4 & 4 & 4 & 19 \\
\hline 33 & Sitti Nurhalisa & 2 & 4 & 4 & 2 & 5 & 2 & 19 \\
\hline 34 & Theo & 5 & 4 & 4 & 3 & - & 2 & 18 \\
\hline 35 & Erlangga Setiawan & 2 & 3 & 1 & 3 & 4 & 3 & 16 \\
\hline 36 & Patri & 5 & 2 & 1 & 3 & 5 & 4 & 18 \\
\hline
\end{tabular}

Data Sources: Class attendance and recapitulation records are absent from homeroom, 2015

From the above data on the second half of the 2015/2016 academic year from January to June 2016 (124 effective days of Study) Prior to the adoption of a scientific-based legal approach, it showed that all 36 students were very vulnerable in attendance, Some students did not come School because there is fear, shame, threatened and so forth, and also the surrounding environment. The influence of the environment is very hard for students to go to school diligently. Every night his friends always invited stay up, hanging out, playing games, and so forth.

Table 2. Recapitulation of absence of grade IX.1 students, after Implementation of Problem students handling through a scientific-based legal approach strategy. For 4 Months (July to October of 2016)

\begin{tabular}{|c|c|c|c|c|c|c|}
\hline \multirow[t]{2}{*}{ No } & \multirow[t]{2}{*}{ Name } & \multicolumn{4}{|c|}{ Amount of Absence (alpha) } & \multirow[t]{2}{*}{ Total } \\
\hline & & July & Agust & Sept & Oct & \\
\hline 1 & Artileri & 1 & 2 & 2 & - & 5 \\
\hline 2 & Al-Fitra Zulhija & 1 & - & 1 & - & 1 \\
\hline 3 & Ananta Dara Dinanti & - & 1 & - & 2 & 3 \\
\hline 4 & Ayu Dwi Maharani & - & 1 & - & - & 1 \\
\hline 5 & Darmin & - & - & - & - & 0 \\
\hline 6 & Erlangga Madjid Lourens & - & 2 & - & - & 2 \\
\hline 7 & Feri Satrio & - & - & - & - & 0 \\
\hline 8 & Iksan Anugrah & 2 & - & 1 & - & 3 \\
\hline 9 & Ira Akib & - & - & - & - & 0 \\
\hline 10 & Muamar Fadil Syah & - & - & 1 & - & 1 \\
\hline 11 & Muh.Reza Pablevy & - & - & - & - & 0 \\
\hline 12 & Muh.Dandi Qimzal & - & 1 & 2 & - & 3 \\
\hline 13 & Muh.Sukur & 1 & - & - & - & 1 \\
\hline 14 & Muh. Syahrian & - & - & - & - & 0 \\
\hline 15 & Purnama Niecco Mossa.Y & - & - & - & - & 0 \\
\hline 16 & Putri Andriani & - & - & 1 & - & 1 \\
\hline 17 & Rahmad Wahyudin & 1 & - & 1 & - & 2 \\
\hline 18 & Rasti Kurmiati Arman & - & 2 & - & - & 2 \\
\hline 19 & Rifkiyanto Maulud Rahim & - & - & 1 & - & 1 \\
\hline 20 & Risal Serentu & - & - & - & - & 0 \\
\hline 21 & Septi Estianti & 1 & - & - & 1 & 2 \\
\hline
\end{tabular}


Troubled Students Handling Through Scientific-Based Law Approach Strategy

\begin{tabular}{|l|l|c|c|c|c|c|}
\hline 22 & Yusril Nazim Mandara & 2 & - & 1 & - & 3 \\
\hline 23 & Irma Yunitha Putri & 1 & - & - & - & 1 \\
\hline 24 & Rina Reski Amalia & - & - & - & - & 0 \\
\hline 25 & Eki Saputra & 1 & - & - & - & 1 \\
\hline 26 & Anjawan & 2 & - & 1 & - & 3 \\
\hline 27 & Awal Pastika Ramadhan & 1 & - & - & 1 & 2 \\
\hline 28 & Stevia & 1 & - & - & 1 & 2 \\
\hline 29 & Aisya Zulhijah & 2 & - & 1 & - & 3 \\
\hline 30 & Rahmasari Safilda & 1 & - & - & 1 & 2 \\
\hline 31 & Dilan & - & 1 & - & 2 & 3 \\
\hline 32 & Adrian & 1 & - & - & 1 & 2 \\
\hline 33 & Sitti Nurhalisa & 2 & - & 2 & - & 4 \\
\hline 34 & Theo & 1 & - & - & - & 1 \\
\hline 35 & Erlangga Setiawan & - & 1 & - & - & 1 \\
\hline 36 & Patri & 1 & - & - & - & 1 \\
\hline
\end{tabular}

Data Sources: Class attendance and recapitulation records are absent from homeroom, 2016

From the above data After the adoption of a scientific-based legal approach in the first semester of the academic year 2016/2017 for 4 months from July till October 2016 (93 effective days Learning), indicating that all students with 36 people already diligently come In this school means That the students' care for education is very good especially in following the Teaching-learning process, some students do not come to school because of illness and permission.

\section{1. from the aspect of the Type of Violation of the Code in the school.}

Based on data on the Recapitulation of violations of discipline for students, as illustrated in Table 3 below, it is evident that prior to the application of handling of the problem of students through scientific-based legal approach strategy of violation of students is very high, this Is because students still do not deeply understand the impact of less behavior Either not even know the legal basis or sanctions The result of the recapitulation of violation of discipline of students, after the application of the handling of the problem of students through a scientific-based legal approach strategy, as illustrated in table 4 below, proved that there is a significant increase of learners towards the implementation of school Rules, students are diligent to attend school precisely Time so that it can follow the morning apple, all have been dressed uniformly according to the time of day set by the school, it is rare students who are late to enter the classroom, maintaining the cleanliness Of the school environment so that there is a school environment that has been done in the field. The willingness of learners to do good, grow from their own conscience, very aware of the things learned by the school that is the study in four agencies. Data on the type of violation of the student-in-law solving student through a scientific-based legal approach can be seen in the following table:

Table 3. Results of Recapitulation of Student Abuse before Implementation of student handling Problematic through a scientific-based legal approach strategy for 6 Months (January to December 2015)

\begin{tabular}{|c|c|c|c|c|c|c|c|c|}
\hline \multirow[t]{2}{*}{ No } & \multirow[t]{2}{*}{ Student's name } & \multicolumn{6}{|c|}{ Type of Violation in Breaking } & \multirow{2}{*}{$\begin{array}{l}\text { Number of } \\
\text { Violations }\end{array}$} \\
\hline & & $\begin{array}{l}\text { Do not follow } \\
\text { Apple Morning } \\
\text { (too late) }\end{array}$ & Bolos & $\begin{array}{l}\text { Uniform } \\
\text { Apparel }\end{array}$ & $\begin{array}{l}\text { Too late } \\
\text { to class }\end{array}$ & $\begin{array}{c}\text { Remove } \\
\text { any } \\
\text { garbage }\end{array}$ & $\begin{array}{l}\text { Not making } \\
\text { homework }\end{array}$ & \\
\hline 1 & Artileri & 35 & 21 & 7 & 28 & 1 & 21 & 113. \\
\hline 2 & Al-Fitra Zulhija & 24. & 5 & 3 & 16 & 1 & 14 & 63 \\
\hline 3 & Ananta Dara Dinanti & 27 & - & 1 & 14 & - & 15 & 57 \\
\hline 4 & Ayu Dwi Maharani & 25 & - & 2 & 18 & - & 21 & 66 \\
\hline 5 & Darmin & 34 & 8 & 1 & 23 & 1 & 24. & 91 \\
\hline 6 & Erlangga Madjid Lourens & 31 & 12 & 1 & 14 & 2 & 18 & 78 \\
\hline 7 & Feri Satrio & 26 & 5 & 3 & 11 & - & 16 & 61 \\
\hline 8 & Iksan Anugrah & 28 & 16 & 5 & 17 & 1 & 9 & 76 \\
\hline 9 & Ira Akib & 11 & 2 & 4 & 13 & - & 14 & 44 \\
\hline 10 & Muamar Fadil Syah & 15 & 4 & 2 & 21 & - & 12 & 54 \\
\hline 11 & Muh.Reza Pablevy & 35 & 8 & 6 & 15 & - & 5 & 69 \\
\hline 12 & Muh.Dandi Qimzal & 24. & 7 & 7 & 13 & - & 8 & 59 \\
\hline 13 & Muh.Sukur & 27 & 9 & 4 & 21 & - & 15 & 76 \\
\hline 14 & Muh. Syahrian & 43 & 3 & 3 & 25 & 2 & 7 & 83 \\
\hline 15 & $\begin{array}{l}\text { Purnama Niecco } \\
\text { Mossa.Y }\end{array}$ & 21 & 5 & 4 & 22 & - & 15 & 67 \\
\hline 16 & Putri Andriani & 25 & 8 & 12 & 24. & - & 23 & 92 \\
\hline 17 & Rahmad Wahyudin & 11 & 4 & 1 & 16 & - & 34 & 66. \\
\hline 18 & Rasti Kurmiati Arman & 9 & - & 4 & 8 & 2 & 18 & 41 \\
\hline 19 & $\begin{array}{l}\text { Rifkiyanto Maulud } \\
\text { Rahim }\end{array}$ & 23 & 2 & 3 & 12 & - & 21 & 61 \\
\hline 20 & Risal Serentu & 21 & 1 & 1 & 15 & 1 & - & 39 \\
\hline 21 & Septi Estianti & 26 & 1 & 5 & 9 & - & 24. & 65 \\
\hline 22 & Yusril Nazim Mandara & 31 & 5 & 3 & 24. & 1 & - & 64 \\
\hline 23 & Irma Yunitha Putri & 22 & 1 & 6 & 16 & - & 17 & 55 \\
\hline 24. & Rina Reski Amalia & 20 & - & 2 & 16 & - & 14 & 52 \\
\hline 25 & Eki Saputra & 21 & 7 & 5 & 15 & 1 & 15 & 64 \\
\hline
\end{tabular}


Troubled Students Handling Through Scientific-Based Law Approach Strategy

\begin{tabular}{|l|l|c|c|c|c|c|c|c|}
\hline 26 & Anjawan & 13 & 5 & 4 & 11 & - & 13 & 46 \\
\hline 27 & Awal Pastika Ramadhan & 12 & 3 & 6 & 6 & 2 & 17 & 46 \\
\hline 28 & Stevia & 16 & - & 2 & 9 & - & 13 & 40 \\
\hline 29 & Aisya Zulhijah & 19 & - & 6 & 14 & 1 & - & 40 \\
\hline 30 & Rahmasari Safilda & 14 & 1 & 3 & 10 & 1 & 6 & 35 \\
\hline 31 & Dilan & 14 & 1 & 5 & 15 & 1 & - & 36 \\
\hline 32 & Adrian & 18 & 1 & 5 & 18 & - & 24. & 66 \\
\hline 33 & Sitti Nurhalisa & 26 & - & 5 & 24 & 2 & - & 57 \\
\hline 34 & Theo & 22 & 3 & 6 & 21 & - & 17 & 69 \\
\hline 35 & Erlangga Setiawan & 23 & 5 & 2 & 16 & - & 21 & 77 \\
\hline 36 & Patri & 27 & 7 & 5 & 18 & 1 & 15 & 73 \\
\hline & TOTAL & 819 & 158 & 144 & 588 & 52 & 506 & 2.267 \\
\hline
\end{tabular}

Data source: Daily picket note, student attendance, class guardian record, data in class Journal And BK teacher reports.

Table 4. Results of Recapitulation of Student Abuse after Application of student handling Problematic through a scientific-based legal approach strategy for 4 months (July, August, September, October 2016)

\begin{tabular}{|c|c|c|c|c|c|c|c|c|}
\hline \multirow[t]{2}{*}{ No } & \multirow[t]{2}{*}{ Student's name } & \multicolumn{6}{|c|}{ Type of Violation in Breaking } & \multirow{2}{*}{$\begin{array}{l}\text { Number of } \\
\text { Violations }\end{array}$} \\
\hline & & $\begin{array}{l}\text { Do not follow } \\
\text { Apple Morning } \\
\text { (too late) }\end{array}$ & Bolos & $\begin{array}{l}\text { Uniform } \\
\text { Apparel }\end{array}$ & $\begin{array}{l}\text { Too } \\
\text { late to } \\
\text { class }\end{array}$ & $\begin{array}{c}\text { Remove } \\
\text { any } \\
\text { garbage }\end{array}$ & $\begin{array}{c}\text { Not } \\
\text { making } \\
\text { homework }\end{array}$ & \\
\hline 1 & Artileri & 11 & 2 & 0 & 4 & 0 & 2 & 19 \\
\hline 2 & Al-Fitra Zulhija & 6 & 0 & 1 & 0 & 0 & 1 & 8 \\
\hline 3 & Ananta Dara Dinanti & 2 & 0 & 1 & 0 & 0 & 1 & 4 \\
\hline 4 & Ayu Dwi Maharani & 7 & 0 & 0 & 2 & 0 & 3 & 12 \\
\hline 5 & Darmin & 2 & 0 & 1 & 1 & 0 & 4 & 8 \\
\hline 6 & $\begin{array}{l}\text { Erlangga Madjid } \\
\text { Lourens }\end{array}$ & 3 & 0 & 0 & 0 & 0 & 2 & 5 \\
\hline 7 & Feri Satrio & 3 & 0 & 2 & 0 & 0 & 0 & 5 \\
\hline 8 & Iksan Anugrah & 4 & 0 & 1 & 0 & 0 & 0 & 5 \\
\hline 9 & Ira Akib & 1 & 0 & 0 & 0 & 0 & 2 & 3 \\
\hline 10 & Muamar Fadil Syah & 1 & 0 & 0 & 0 & 0 & 3 & 4 \\
\hline 11 & Muh.Reza Pablevy & 8 & 0 & 0 & 2 & 0 & 0 & 10 \\
\hline 12 & Muh.Dandi Qimzal & 2 & 0 & 0 & 1 & 0 & 2 & 5 \\
\hline 13 & Muh.Sukur & 1 & 0 & 1 & 0 & 0 & 1 & 3 \\
\hline 14 & Muh. Syahrian & 2 & 0 & 1 & 0 & 0 & 1 & 4 \\
\hline 15 & $\begin{array}{l}\text { Purnama Niecco } \\
\text { Mossa.Y }\end{array}$ & 3 & 0 & 0 & 2 & 0 & 3 & 8 \\
\hline 16 & Putri Andriani & 2 & 0 & 1 & 1 & 0 & 2 & 6 \\
\hline 17 & Rahmad Wahyudin & 3 & 0 & 0 & 0 & 0 & 6 & 9 \\
\hline 18 & Rasti Kurmiati Arman & 3 & 0 & 2 & 0 & 0 & 0 & 5 \\
\hline 19 & $\begin{array}{l}\text { Rifkiyanto Maulud } \\
\text { Rahim }\end{array}$ & 0 & 0 & 1 & 0 & 0 & 1 & 2 \\
\hline 20 & Risal Serentu & 0 & 0 & 0 & 0 & 0 & 2 & 2 \\
\hline 21 & Septi Estianti & 3 & 0 & 0 & 2 & 0 & 5 & 10 \\
\hline 22 & Yusril Nazim Mandara & 2 & 0 & 0 & 1 & 0 & 0 & 3 \\
\hline 23 & Irma Yunitha Putri & 1 & 0 & 0 & 1 & 0 & 2 & 4 \\
\hline 24. & Rina Reski Amalia & 0 & 0 & 1 & 0 & 0 & 4 & 5 \\
\hline 25 & Eki Saputra & 2 & 0 & 1 & 0 & 0 & 1 & 4 \\
\hline 26 & Anjawan & 0 & 0 & 0 & 2 & 0 & 3 & 5 \\
\hline 27 & $\begin{array}{l}\text { Awal Pastika } \\
\text { Ramadhan }\end{array}$ & 2 & 0 & 1 & 1 & 0 & 4 & 8 \\
\hline 28 & Stevia & 3 & 0 & 0 & 0 & 0 & 2 & 5 \\
\hline 29 & Aisya Zulhijah & 1 & 0 & 2 & 2 & 0 & 0 & 5 \\
\hline 30 & Rahmasari Safilda & 2 & 0 & 1 & 2 & 0 & 5 & 10 \\
\hline 31 & Dilan & 2 & 0 & 2 & 0 & 0 & 2 & 6 \\
\hline 32 & Adrian & 3 & 0 & 0 & 2 & 0 & 5 & 10 \\
\hline 33 & Sitti Nurhalisa & 2 & 0 & 0 & 1 & 0 & 0 & 3 \\
\hline 34 & Theo & 1 & 0 & 0 & 1 & 0 & 2 & 4 \\
\hline 35 & Erlangga Setiawan & 3 & 0 & 1 & 0 & 0 & 4 & 8 \\
\hline 36 & Patri & 2 & 0 & 1 & 0 & 0 & 1 & 4 \\
\hline & TOTAL & & & & & & & \\
\hline
\end{tabular}

Data source: Daily picket note, student attendance, class guardian record, data in class Journal And BK teacher reports.

\section{From the aspect of Classroom Learning Process.}

After the authors identify the vulnerable students, and collect in a class that is class IX.1 as the guardian class is the principal, then the entire class IX no longer appears to show symptoms of vulnerability, both in the learning process provided by teachers and Other activities that are academic and curricular. 


\section{The effects of this separation of learners are:}

A. Classroom learning activities are effective, fun and enjoyable. The learning process in the classroom is effective, and fun, the activity of the students raises the mental / intellectual involvement, especially the intellectual-emotional involvement in the study group. Examples of mental involvement are listening to lectures, discussing, observing, solving problems, and so on. Emotional involvement can be appreciation of feelings, values, attitudes, strengthening motivation, and so on in the development of affective sphere. Similarly, physical involvement in a variety of direct actions with specific and immediate feedback in the formation / development of the psychomotor domain. All of this is well built so that the learning objectives are well achieved.

\section{B. Loss of noise.}

An educator when teaching in the class of course often encountered obstacles. One of the most common obstacles is students who are in love with their friends, they do not pay attention to what the teacher explains in front. They are busy themselves. Usually they talk to friends who are on the right and left. Usually they play a game. With the separation of students who are always on the subject of identification of the students prone then the current learning process goes well, no longer noisy, the teacher of science is also very well, teachers also feel calm and concentrated on the Learning model PAIKEM, teachers easily develop Skill enhancement strategies and techniques that not only enable students beyond the level of achievement, but also boost their personal interactions with others. Easily integrated with the 2013 curriculum taught at SMPN 17 Kendari, study skills and life skills can give students excitement in learning. These findings are consistent with De Porter's (1999: 109) that is the sharpness that drives them to be Quantum Learners and Quantum Communicators. It goes on to say that students can show passion for life, eachers easily connect with diverse students, Always associate any information with the student's life experience and care about the student's self. Prefer the interaction in the learning environment, pay attention to the quality of the interaction between students, between students and teachers, and between students and the curriculum.

\section{Conclusion}

From the above explanation about the handling of problem students through a scientific-based legal approach strategy in handling troubled students at SMPN 17 Kendari, it can be concluded things as follows:

1. The principal as a leader, has the responsibility to mobilize, encourage Human Resources and especially teachers to enable them to participate and carry out their tasks as expected to achieve the school goals and educational objectives in general.

2. Application of handling of problem students through a scientific-based legal approach strategy is a strategy to bring students in developing and fostering patterns of thought and character to change normal life behavior so that faith and piety in school can be entrusted for the personal integrity Of the nation's children, and gave birth to disciplined students, Achievers, firm faith and excel in the mastery of technology.

3. Handling of problem students through scientific-based legal approach strategy is a real effort made by SMP Negeri 17 Kendari can create a creative, innovative and fun learning atmosphere so that student learning outcomes can increase.

\section{References}

[1]. Afriani Fitri (2004). Strategi Guru Dalam Memotivasi Siswa Meningkatkan Prestasi Belajar.

[2]. Dawi (2008). Strategi Bidan dalam Memotivasi Ibu-Ibu membawa Anaknya Ke Posyandu De Porter, Bobbi (1999) Quantum Teaching.Mempraktekkan Quantum Learning di ruang- Ruang Kelas.Penerbit Kaifa. Bandung.

[3]. Dorothy Rich, (2008) Pengajaran dan Bimbingan Sekolah menengah.Menjaga Tetap Dalam Jalur Pembelajar yang Disiplin.PT.Indeks. Jakarta.

[4]. Gunarsa.2004.Psikologi perkembangan anak dan remaja. publiser.jakarta.Gunung Mulia Hurlock Elizabeth B. (2010) Perkembangan anak, jilid 1 .jakarta.Erlangga Sumiati, dkk. 2009. Kesehatan Jiwa Remaja \& Konseling. Jakarta: Trans Info Media. 